\title{
Functional neural differentiation of human adipose tissue-derived stem cells using bFGF and forskolin
}

\author{
Sujeong Jang 1,3,4, Hyong-Ho Cho 2,4, Yong-Bum Cho*2,4, Jong-Seong Park1,3,4 and Han-Seong Jeong*1,3,4
}

\begin{abstract}
Background: Adult mesenchymal stem cells (MSCs) derived from adipose tissue have the capacity to differentiate into mesenchymal as well as endodermal and ectodermal cell lineage in vitro. We characterized the multipotent ability of human adipose tissue-derived stem cells (hADSCs) as MSCs and investigated the neural differentiation potential of these cells.

Results: Human ADSCs from earlobe fat maintained self-renewing capacity and differentiated into adipocytes, osteoblasts, or chondrocytes under specific culture conditions. Following neural induction with bFGF and forskolin, hADSCs were differentiated into various types of neural cells including neurons and glia in vitro. In neural differentiatedhADSCs (NI-hADSCs), the immunoreactivities for neural stem cell marker (nestin), neuronal markers (Tuj1, MAP2, NFL, NFM, NFH, NSE, and NeuN), astrocyte marker (GFAP), and oligodendrocyte marker (CNPase) were significantly increased than in the primary hADSCS. RT-PCR analysis demonstrated that the mRNA levels encoding for ABCG2, nestin, Tuj1, MAP2, NFL, NFM, NSE, GAP43, SNAP25, GFAP, and CNPase were also highly increased in NI-hADSCs. Moreover, NIhADSCs acquired neuron-like functions characterized by the display of voltage-dependent tetrodotoxin (TTX)sensitive sodium currents, outward potassium currents, and prominent negative resting membrane potentials under whole-cell patch clamp recordings. Further examination by RT-PCR showed that NI-hADSC expressed high level of ionic channel genes for sodium (SCN5A), potassium (MaxiK, Kv4.2, and EAG2), and calcium channels (CACNA1C and (ACNA1G), which were expressed constitutively in the primary hADSCs. In addition, we demonstrated that Kv4.3 and Eag1, potassium channel genes, and NE-Na, a TTX-sensitive sodium channel gene, were highly induced following neural differentiation.

Conclusions: These combined results indicate that hADSCs have the same self-renewing capacity and multipotency as stem cells, and can be differentiated into functional neurons using bFGF and forskolin.
\end{abstract}

\section{Background}

Stem cell-based therapies for the repair and regeneration of various tissues and organs offer a paradigm shift that may lead to alternative therapeutic solutions for a number of diseases. The emerging field of regenerative medicine requires reliable sources of stem cells, biomaterial scaffolds and cytokine growth factors. A stem cell is characterized by its ability to self-renew and to differentiate along multiple lineage pathways. The multi-lineage potentials of embryonic stem cells (ESCs) and adult stem

*Correspondence: choyb_cnu@hanmail.net, jhsjeong@hanmail.net 1 Department of Physiology, Chonnam National University Medical School, Gwangju 501190, Republic of Korea

2 Department of Otolaryngology, Chonnam National University Medical School, Gwangju 501190, Republic of Korea cells from bone marrow have been extensively documented [1-4]. Although ESCs have been isolated from humans and have enormous potential, their use in therapeutics is restricted by ethical and political issues $[5,6]$. Compared to ESCs, adult stem cells have diminished selfrenewal capability and multipotency. By nature, however, adult stem cells are immunocompatible and there are no ethical issues related to their use. The advantage of using mesenchymal stem cells (MSCs) over other cell types is the ability to take advantage of their autologous properties [7-11]. MSCs can easily be obtained from the patient's own tissue, including bone marrow, adipose tissue, cartilage, synovium, periosteum, muscle, and palatine tonsil and expanded vigorously until the tissues differentiate into specific cell lineages [12-21].

\section{Full list of author information is available at the end of the article}

() 2010 Jang et al; licensee BioMed Central Ltd. This is an Open Access article distributed under the terms of the Creative Commons B. Wed Central Attribution License (http://creativecommons.org/licenses/by/2.0), which permits unrestricted use, distribution, and reproduction in any medium, provided the original work is properly cited. 
Neural tissue is understood to have a limited capacity for repair after injury, and adult neurogenesis is limited to selected regions of the brain, including the hippocampus, the subventricular zone, and the olfactory system $[22,23]$. Therefore, a broad spectrum of cells capable of neuronal differentiation is required for cell replacement therapies. Adult peripheral tissues may be an alternative source of stem and progenitor cells. For example, a number of studies have shown that adult bone marrow contains a population of mesenchymal stem cells capable of differentiating into several lineages, including neuronal and glial tissues [2,13,24-29]. However, bone marrow procurement is extremely painful for patients and yields low numbers of harvested cells.

Adipose tissue is emerging as a source of stem cells obtained by less invasive methods including lipoaspiration, and in larger quantities than bone marrow. Adipose tissue, like bone marrow, is derived from the embryonic mesoderm and contains a heterogeneous stromal cell population that includes mature adipocytes, preadipocytes, fibroblasts, vascular smooth muscle cells, endothelial cells, monocyte/macrophages, and lymphocytes [30]. Adipose tissue-derived stem cells (ADSCs) are selfrenewing and can differentiate along several mesenchymal tissue lineages, including adipocytes, osteoblasts, myocytes, chondrocytes, endothelial cells, and cardiomyocytes [14,31-35]. Since human adipose tissue is ubiquitous and easily obtained in large quantities under local anesthesia with little patient discomfort, it may present an alternative source of stem cells for mesenchymal tissue regeneration and engineering.

Recent studies report that ADSCs can also be induced into neuron- or glia-like cells in vitro $[12,20,36-40]$, but whether MSCs can actually differentiate into neurons and glia remains controversial $[41,42]$. The neuron-like morphology and immunocytochemical expression for neural markers in transdifferentiated bone marrow-derived MSCs under culture or in vivo conditions may be due to cell fusion [43-45]. On the contrary, some investigators have demonstrated that neural differentiation is induced independently of cell fusion [46], indicating either that MSCs have an intrinsic ability for differentiation beyond their organ of residence or that MSC differentiation potential can be reprogrammed toward specific cell lineages by exogenous cues [47]. These results imply that the capacity of ADSCs for neural differentiation should be evaluated functionally and morphologically.

This study aimed to examine whether neurally-induced hADSCs (NI-hADSCs) displayed the functional characteristics of neural cells. We have characterized the multipotent capacity of hADSCs isolated from earlobe fat and investigated the differentiation potential of stem cells into neural cells in the presence of bFGF and forskolin, which are known to enhance the neuronal differentiation of bone marrow-derived MSCs [26] over two weeks. We identified that NI-hADSCs displayed voltage-dependent and TTX-sensitive sodium currents, which are a functional hallmark of neurons, and expressed high levels of ionic channel genes, which are important in neural function.

\section{Results}

\section{Isolation and characterization of adipose tissue-derived} stem cells

Human mesenchymal stem cells were isolated from earlobe fat according to their adherence to culture dishes containing DMEM supplemented with 10\% FBS. The cells were expanded after plating and grown to confluence. Approximately four weeks into the culture, cells became more uniform and grew in a monolayer with typical fibroblast-like morphology (Figure 1a). The proliferation of human adipose tissue-derived stem cells (hADSCs) remained consistent up until the 15th passage.

To clarify the isolated hADSCs, we performed FACS analysis with various cell surface markers, including MSC-specific cell type markers and hematopoietic stem cell markers (Table 1). As shown in Figure 1b, more than 95\% of the adipose tissue-derived hMSCs expressed MSC-specific markers, including CD13, CD44 (endoglin), CD90 (Thy-1), and CD166, but did not express markers for hematopoietic stem cells, including CD14, CD34, and CD45. Thus, hADSCs in this experiment appeared to be MSCs.

\section{Pluripotent capability of hADSCs}

To determine whether hADSCs are pluripotent and able to differentiate into various cell types in vitro, hADSCs were cultured in selection media. Human ADSCs did not spontaneously differentiate during culture expansion. The differentiation of hADSCs into adipocytes, osteoblasts, and chondrocytes were also confirmed by specific staining and RT-PCR analysis (Figure 2). After one week of the adipogenic culture medium culture, more than $90 \%$ of the cells differentiated into lipid-laden cells that were stained with oil-red O. Lipoprotein lipase was markedly expressed in adipogenic cultured cells (Figure 2a). After two weeks of the osteogenic medium culture, the cells differentiated into osteoblasts, which were confirmed with strong alkaline phosphatase staining. The RNA expression of osteopontin in osteogenic cultured cells was higher than that of the control cells. Parathyroid hormone (PTH) receptor was also expressed in osteogenic cultured hADSCs, indicating differentiation into osteoblasts (Figure 2b). Differentiation of hADSCs into chondrocytes was determined by staining with Alcian blue, which identifies the proteoglycan extracellular matrix, a specific component of cartilage tissues. Compared to expression in the control cells, the relative RNA expres- 


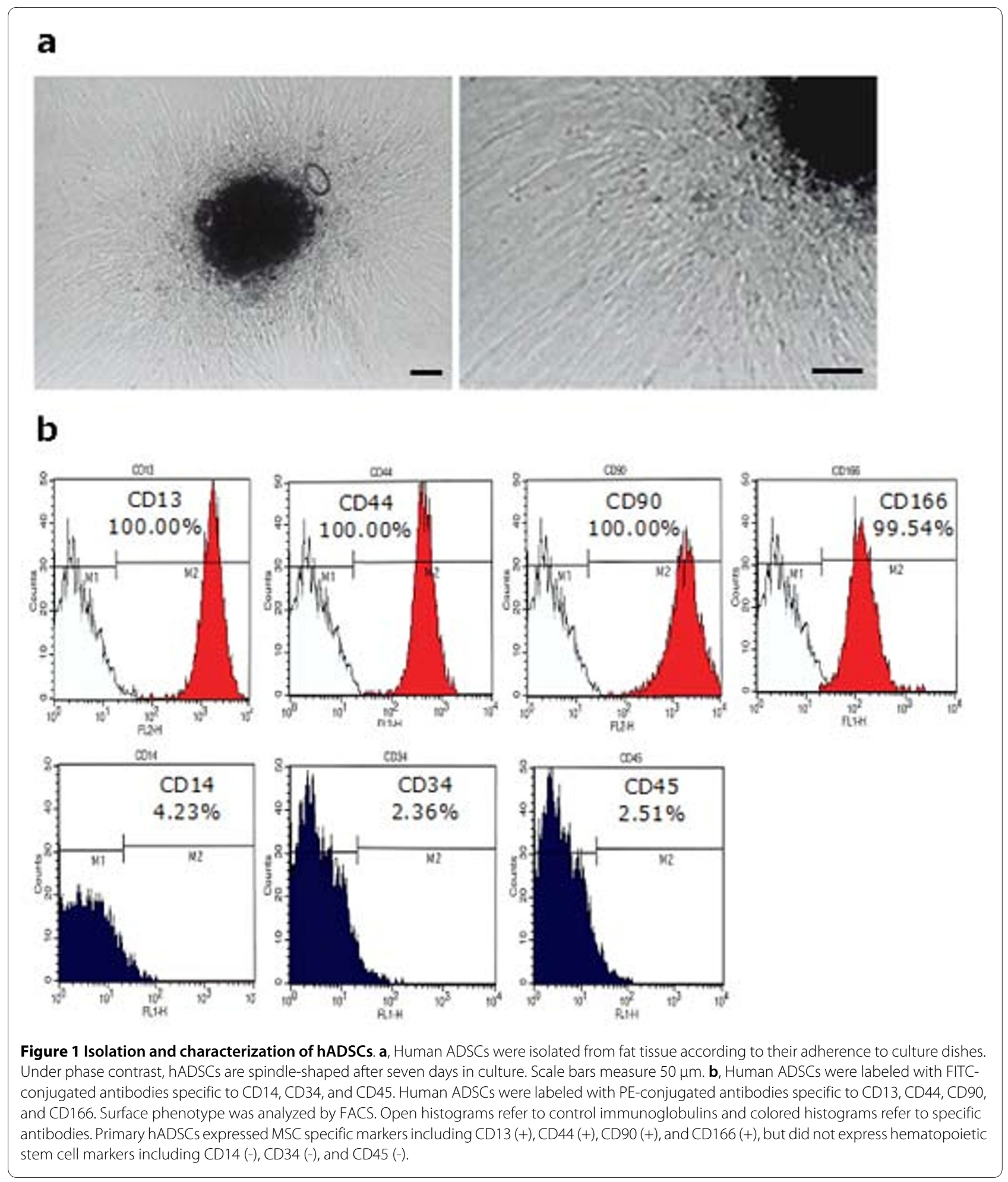

sion of periecan and collagen type II in chondrogenic cultured cells increased significantly (Figure 2c). These results demonstrate that hADSCs have an intrinsic plasticity regarding differentiation into various mesodermal lineage cells.

\section{Neural differentiation of hADSCs in vitro}

For neural induction, hADSCs were incubated with growth medium supplemented with bFGF for seven days, and then incubated in DMEM with forskolin for the next seven days. In neurally differentiated hADSCs, immuno- 
Table 1: Phenotypic analysis of hMSCs with FACS

\begin{tabular}{|c|c|c|}
\hline Antigen & Description & $(+) /(-)$ \\
\hline CD13 & Bone marrow stromal cell marker & $(+)$ \\
\hline CD44 & Endoglin receptor & $(+)$ \\
\hline CD90 (Thy-1) & Endothelial cell marker & $(+)$ \\
\hline CD166 & Cell adhesion molecule & $(+)$ \\
\hline CD14 & Lipopolysaccharide receptor & $(-)$ \\
\hline CD34 & Hematopoietic progenitor cell marker & $(-)$ \\
\hline CD45 & Hematopoietic progenitor cell marker & $(-)$ \\
\hline
\end{tabular}

reactivities for neural stem cell markers (nestin), neuronal markers (Tuj1, MAP2, NFL, NFM, NFH, NSE, and NeuN), synaptic markers (GAP43 and SNAP25), astrocyte marker (GFAP), and oligodendrocyte marker (CNPase) were very high when grown in the presence of bFGF and forskolin supplements (Figure 3a, 3b). After neural differentiation, the majority of NI-hADSCs exhibited distinct bipolar or multipolar morphologies with branched processes, which was well visualized by the immunocytochemistry of the somatodendritic marker, MAP2, and the axonal marker, GAP43 (Figure 3a). In basal hADSCs, the portion of hADSCs expressing cell type specific markers was very low. Marker-positive cells increased considerably with neural supplements. Following terminal differentiation with bFGF and forskolin, a large number of neural marker-positive neurons were observed in cultures when compared with that of GFAPpositive astrocytes and CNPase-positive oligodendrocytes (Figure 3b).

Reverse-transcription polymerase chain reaction analysis was used to monitor the extent of neural differentiation in mRNA levels of the stem cells. In NI-hADSCs, mRNA levels encoding for ABCG2, a neural stem cell marker, nestin, Tuj1, MAP2, NFL, NFM, NSE, GAP43, SNAP25, GFAP, and CNPase were higher compared with primary hADSCs (Figure 3c, 3d).

To assess whether NI-hADSCs were differentiated into functional neurons, electrophysiological properties were tested in basal hADSCs and following neural differentiation using the patch clamp technique in whole-cell configuration. Primary hADSCs grown in the regular media in the absence of bFGF and forskolin were quiescent, exhibiting virtually no sodium current $(n=24$, data not shown), which is responsible in both initiation and propagation of neural action potentials throughout the nervous system. However, following differentiation with bFGF and forskolin for two weeks, more than $75 \%$ of the NIhADSCs expressed prominent voltage-dependent sodium currents up to $1.2 \mathrm{nA}$ (18 of 24 cells). The mean peak amplitude of voltage-dependent sodium currents at $-20 \mathrm{mV}$ was $-605 \pm 36 \mathrm{pA}(\mathrm{n}=18$, Figure $4 \mathrm{a})$. Sodium currents were blocked by $100 \mathrm{nM}$ tetrodotoxin (TTX). Along with sodium current induction, hADSCs grown with differentiation factors demonstrated sustained outward currents, which exhibited voltage-dependence and kinetic characteristics for delayed rectifier potassium currents (Figure 4b). Under current clamp conditions, the resting membrane potential of neurally differentiated hADSC ($58.58 \pm 8.46 \mathrm{mV}, \mathrm{n}=24$ ) was recorded to be significantly more negative than that of control hADSCs $(-15.47 \pm 5.13$ $\mathrm{mV}, \mathrm{n}=24 ; P<0.001$, Fig. $4 \mathrm{c}$ ).

In addition to functional studies, mRNA expression for ion channels related to outward and inward currents was investigated in primary- and NI-hADSCs with RT-PCR using specific primers (Table 2). In ADSCs, ion channel protein or gene expression has not yet been reported. The primary hADSCs expressed MaxiK (responsible for human large-conductance, voltage- and calcium-dependent $\mathrm{K}^{+}$channel), Kv1.4 and Kv4.2 (human voltagedependent $\mathrm{K}^{+}$channel), Eag2 (human ether-á-go-go $\mathrm{K}^{+}$ channel), SCN5A (TTX-insensitive $\mathrm{Na}^{+}$channel), CACNA1C (human voltage-dependent L-type $\mathrm{Ca}^{2+}$ channel, alpha $1 \mathrm{C}$ subunit), and CACNA1G (human voltagedependent T-type $\mathrm{Ca}^{2+}$ channel, alpha $1 \mathrm{G}$ subunit) constitutively. However, primary hADSCs did not express Kv4.3 (human voltage-dependent $\mathrm{K}^{+}$channel), Eag1 
a
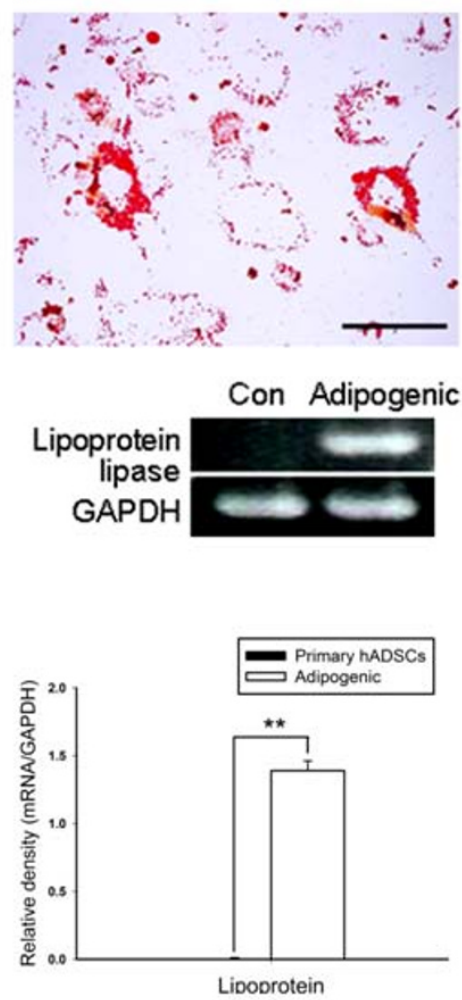

b
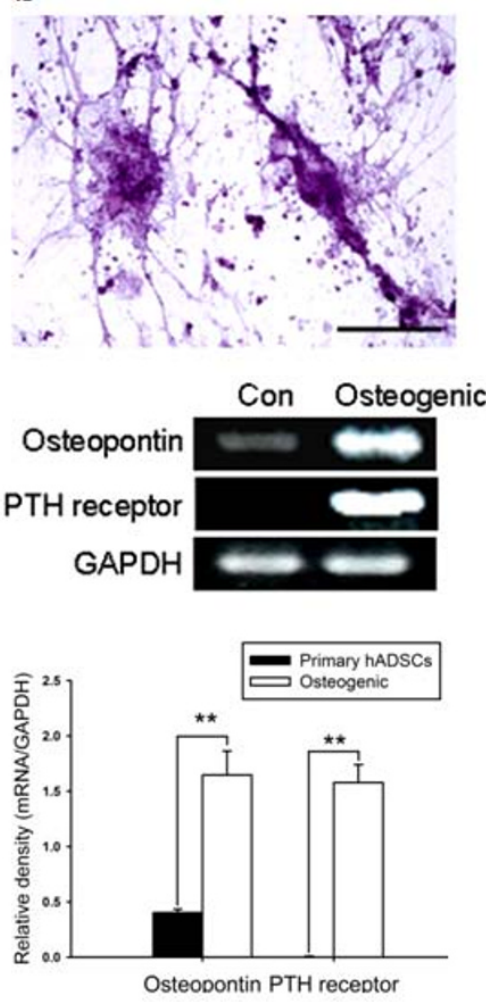

C
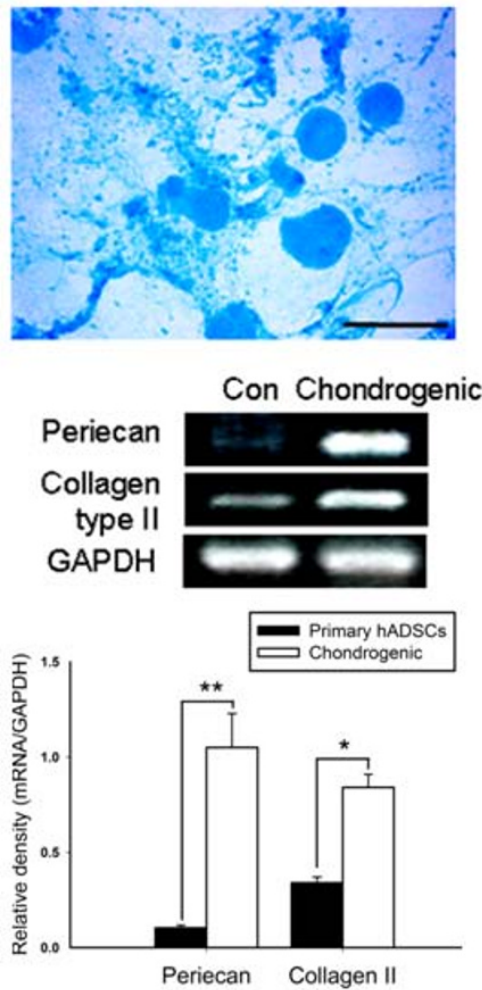

Figure 2 Investigation of the multipotent capacity of hADSCs using immunostaining and RT-PCR analysis. a, Cells were cultured for one week in selection media specifically designed for adipogenic differentiation. Adipogenic differentiation is shown with oil-red O staining and RT-PCR analysis for lipoprotein lipase. b. Cells were cultured for two weeks in selection media specifically designed for osteogenic differentiation. Osteogenic differentiation is shown with alkaline phosphatase staining and RT-PCR analysis for osteopontin and PTH receptor. c, Cells were cultured for three weeks in selection media specifically designed for chondrogenic differentiation. Chondrogenic differentiation is shown with Alcian blue staining and RT-PCR analysis for periecan and collagen type II. Scale bars measure $50 \mu \mathrm{m}$. GAPDH was used as a control. The intensity of each gene was normalized to GAPDH and these results were repeated at least five times. ${ }^{*} P<0.05,{ }^{* *} P<0.01$ compare with the primary hADSCs.

(human ether-á-go-go $\mathrm{K}^{+}$channel), or NE-Na (TTX-sensitive $\mathrm{Na}^{+}$channel). Following neural differentiation with bFGF and forskolin, the gene expression levels of MaxiK, Kv4.2, Eag2, SCN5A, CACNA1C, and CACNA1G in NIhADSCs were significantly higher than in the primary hADSCs (Figure 4d, 4e). Furthermore NI-hADSCs expressed Kv4.3, Eag1, and NE-Na. These results indicate that the hADSCs were effectively developed into functional neuron-like cells and thereby expressed neuronspecific phenotypes after being differentiated in vitro.

\section{Discussions}

Our results demonstrate that ADSCs isolated from human earlobe fat express MSC-specific markers and can be differentiated into neural cells via bFGF- and forskolin-dependent pathways. In addition, NI-hADSCs have neural markers and functional neuron-like characteristics.

In the present study, the phenotypic expression of hADSCs is consistent over culture passages and the mor- phological features are the same as those previously reported $[12,34,48,49]$. Adipose tissue-derived stem cells are understood to express surface markers of CD9, CD10, CD13, CD29, CD44, CD49d, CD49e, CD54, CD55, CD59, CD73, CD90, CD105, CD146, CD166, and STRO-1, and lack hematopoietic lineage markers CD11b, CD14, CD19, CD34, and CD45 [20,34,50-53]. The hADSCs expressed MSC-specific cell type markers including CD13, CD44, CD90, and CD166, however, did not express CD14, CD34, and CD45 indicating that hADSCs in this study were of mesenchymal origin. Adipose tissue-derived stem cells also seem to possess the capacity to differentiate into multiple mesodermal lineages such as bone, fat, and cartilage $[31,34]$. The current study supports this hypothesis, characterizing the expression of multiple lineage-specific genes and proteins including adipocytes, osteoblasts, and chondrocytes. This observation has led us to speculate that adipose tissue may be a valuable source of mesodermal stem cells. 


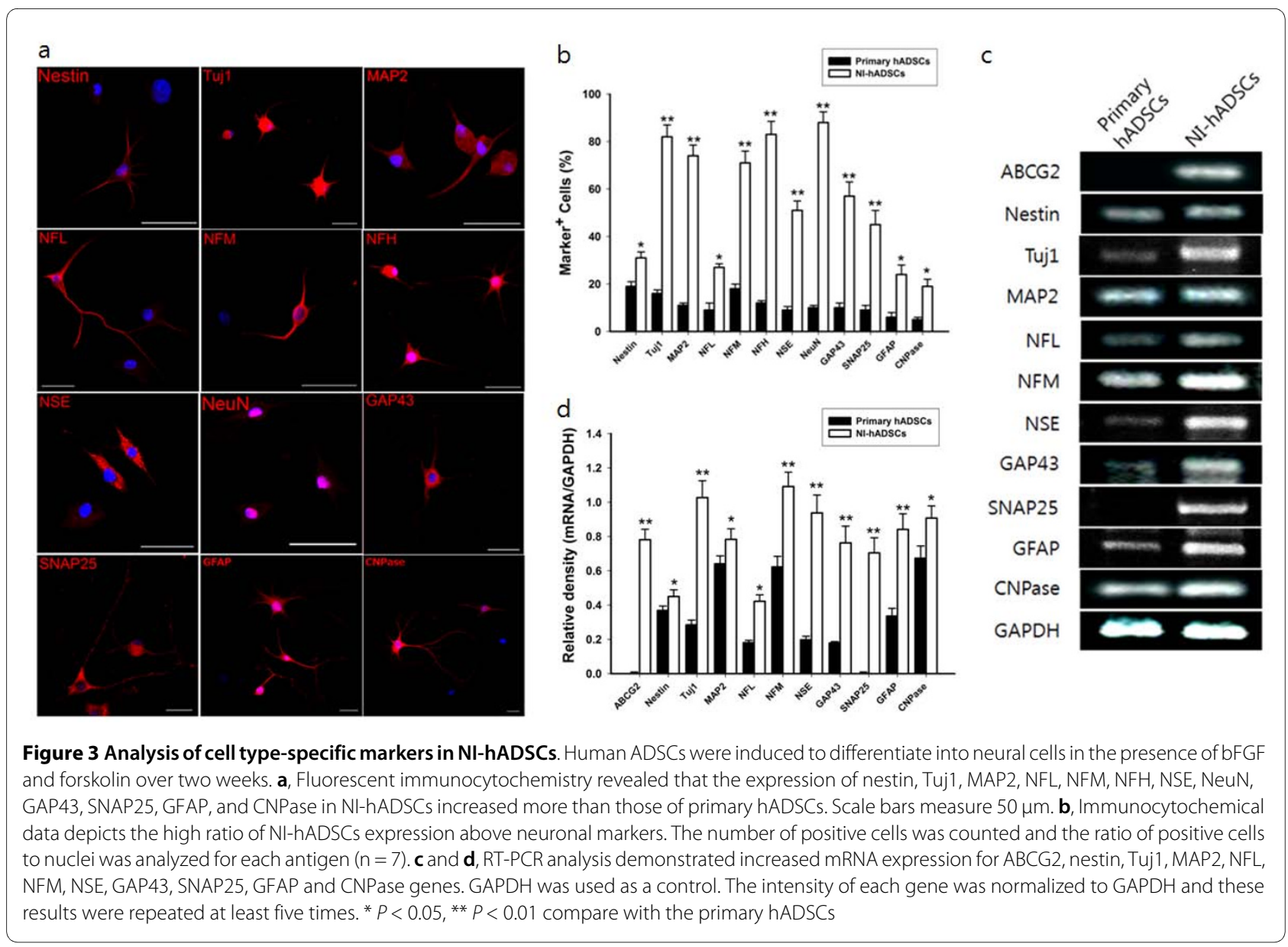

Reports indicate that the neural differentiation of ADSCs is achieved with different experimental protocols, Protocols include using chemical agents like $\beta$-mercaptoethanol[34,35], a mix of valproic acid, butylated hydroxyanisole, insulin, hydrocortisone [38,39,54], azacytidine [55,56], or a cocktail of isobutylmethylxanthine, indomethacin, and insulin $[48,57,58]$. A mixture of glial growth factors [36], a mixture including bFGF and platelet-derived growth factor [59], or brain-derived neurotrophic factor (BDNF) with retinoic acid [12] also evoked the neural induction of ADSCs in vitro. In addition, rodent ADSCs are differentiated into Schwann celllike cells by a procedure that involves making floating neurospheres [40]. In bone marrow-derived MSCs, neural differentiation was induced via transfection of proneural genes [25], treatment with bFGF, forskolin and ciliary neurotrophic factor (CNTF) [9] or co-culture with neural cells $[2,46]$. In the present study, we used bFGF and forskolin to induce the neural differentiation of hAD$\mathrm{SCs}$ because bFGF is known to generate neural precursor cells with a greater capacity for neuronal differentiation $[9,26,60]$. Contrary to bFGF, epidermal growth factor and cilliary neurotrophic factor are reported to restrict astro- cyte lineages. Forskolin is a commonly used agent to increase the intracellular levels of cyclic adenosine monophosphate (cAMP) by activating the enzyme adenylyl cyclase. Furthermore, forskolin is reported to induce the neuron-like morphology and expression of NSE, NFH, and Tuj 1 in human MSCs cultured in serum-free conditions $[61,62]$. Our experiments demonstrate that NIhADSCs express increased immunoreactivities for neuronal markers Tuj1, MAP2, NFL, NFM, NFH, NSE, NeuN, GAP43, and SNAP25, as well as the increased mRNA expression of Tuj1, MAP2, NFL, NFM, NSE, GAP43, and SNAP25 compared to primary hADSCs (Figure 3), indicating that hADSCs differentiate into neural cells via bFGF and forskolin-mediated differentiation. Much like neuronal cells derived from other MSCs or embryonic stem cells $[63,64]$, in vitro-transdifferentiated hADSCs also exhibited neuronal cell properties.

According to previous reports about neurogenic differentiation, ADSCs exhibit neuron-like morphology and express several proteins and genes consistent with the neuronal phenotype $[20,35,54,57-59,65]$. However, reliance on neural marker expression as an indicator of neurally differentiated MSCs has become unreliable because 


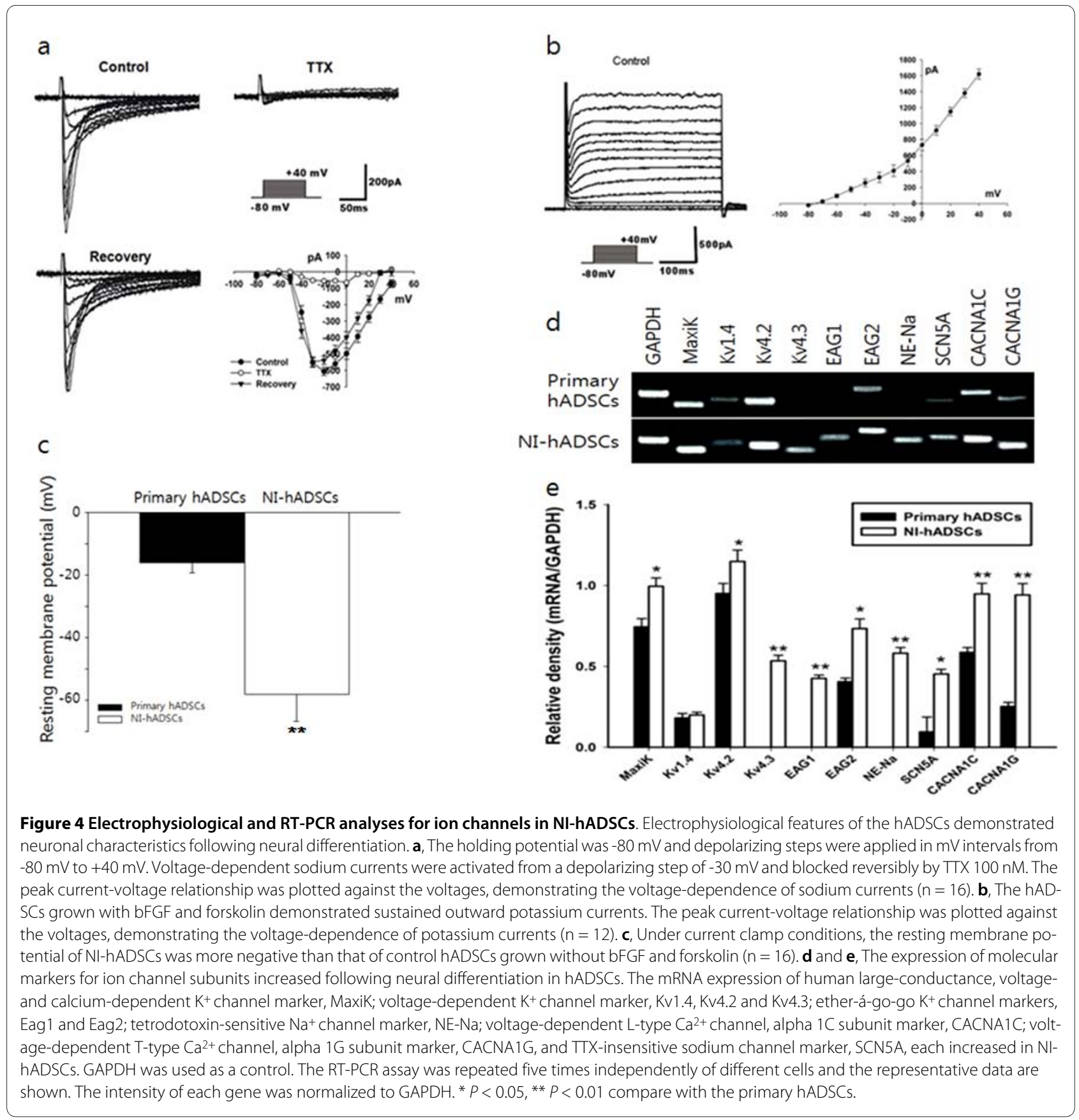

undifferentiated MSCs express several neural markers at both the mRNA and protein levels $[42,66]$. Adult mesenchymal stem cells constitutively express native immature neural proteins (nestin and Tuj1), whereas more mature neuronal and glial proteins (tyrosine hydroxylase, MAP2, and GFAP) are expressed in increasing passage numbers $[67,68]$. Undifferentiated ADSCs also express markers characteristic of neural cells such as NSE, vimentin, and NeuN [57]. In addition, inter-donor variability of expression of neural marker genes in MSC samples needs to be considered [42]. We therefore performed electrophysio- logical studies to investigate whether NI-hADSCs demonstrate the functional properties of mature neurons. Through patch-clamp recordings, NI-hADSCs were identified to generate prominent TTX-sensitive voltagedependent sodium currents and outward potassium currents, both of which are hallmarks of mature neurons and crucial for signal transmission in the nervous system. In contrast to bone marrow-derived MSCs, in which combination of bFGF, forskolin, and CNTF was not sufficient to induce voltage-dependent sodium current [9], hADSCs expressed the sodium current by treatment of bFGF and 
Table 2: Sequence of PCR primers

\begin{tabular}{|c|c|c|}
\hline Gene & Sense & Antisense \\
\hline Lipoprotein lipase & СTTCTGTTCTAGGGAGAAAGTG & TGCTGTGTAGATGAGTCTGATT \\
\hline Osteopontin & GAAGGACAGTTATGAAACGAGT & AACATAGACATAACCCTGAAGC \\
\hline PTH receptor & AACTACTACTGGATTCCTGGTGG & CTCCAAGATTTCTTGATCTCAG \\
\hline Periecan & CATAGAGACCGTCACAGCAAG & ATGAACACCACACTGACAACC \\
\hline Collagen type II & ACGGCGAGAAGGGAGAAGTTG & GGGGGTCCAGGGTTGCCATTG \\
\hline ABCG2 & CAAAACTTGCTGGGTAATC & ACAGAAACCACACTCTGACC \\
\hline Nestin & CTCTGACCTGTCAGAAGAAT & GACGATGACACTTACAGAAT \\
\hline Tuj1 & CATGGATGCCGCTCAG & CAGGCAGTCGCAGTITTCAC \\
\hline MAP2 & TGCCATCTTGGTGCCGA & CTTGACATTACCACCTCCAGGT \\
\hline NFL & TCCTACTACACCAGCCATGT & TCCCCAGCACCTTCAACTIT \\
\hline NFM & TGGGAAATGGCTCGTCATTT & CTTACTGGAAGCGGCCAATT \\
\hline NSE & CTGATGCTGGAGTTGGATGG & CCATTGATCACGTTGAAGGC \\
\hline GAP43 & TCCTGAGCCCTGTCTCTCCCT & GCCACACTGTTTGACTTGGG \\
\hline SNAP25 & AGTTGGCTGATGAGTCGCTG & TGAAAAGGCCACAGCATTTC \\
\hline GFAP & GCAGAGATGATGGAGCTCAATGACC & GTTTCATCCTGGAGCTTCTGCCTCA \\
\hline CNPase & GGCCACGCTGCTAGAGTGCAAGAC & GGTACTGGTACTGGTCGGCCATTT \\
\hline MaxiK & ACAACATCTCCCCCAACC & ТСАТСАССТTСТTСССАТТС \\
\hline Kv1.4 & ACGAGGGCTITGTGAGAGAA & CACGATGAAGAAGGGGTCAT \\
\hline Kv4.2 & ACCGTGACCCAGACATCTTC & CACTGTTTCCACCACATTCG \\
\hline Kv4.3 & GCCTCCGAACTAGGCTTTCT & CCCTGCGTITATCAGCTCTC \\
\hline EAG1 & TGGATITGCAAGCTGTCTG & GAGTCTTTGGTGCCTCTTGC \\
\hline EAG2 & ACATCCTGCTITTCGATTGG & CGGCTCTCTACCTGGCGTTG \\
\hline
\end{tabular}


Table 2: Sequence of PCR primers (Continued)

\begin{tabular}{lll}
\hline NE-Na & GCTCCGAGTCTTCAAGTTGG & GGTTGTTTGCATCAGGGTCT \\
\hline SCN5A & CCTAATCATCTTCCGCATCC & TGTTCATCTCTCTGTCCTCATC \\
\hline CACNA1C & AACATCAACAACGCCAACAA & AGGGCAGGACTGTCTTCTGA \\
\hline CACNA1G & CTGCCACTTAGAGCCAGTCC \\
\hline GAPDH & TCTGAGTCAGGCATTTCACG \\
\hline
\end{tabular}

forskolin. Furthermore, NI-hADSCs exhibited about -58 $\mathrm{mV}$ of resting membrane potential, indicating that they also have functional characteristics of neurons.

Recently, Anghileri et al. reported electrophysiological evidence of neuronal differentiation [12]. After differentiation with BDNF and retinoic acid, hADSC exhibited immunocytochemical evidence of neuronal differentiation in only $57 \%$ of cells and mean peak amplitude of approximately -189 pA for voltage-dependent $\mathrm{Na}^{+}$currents in differentiated hADSCs. Ashjian et al. also demonstrated that supplementation with isobutylmethylxnthine (IBMX), indomethacin and insulin induced transdifferentiation of human processed lipoaspirate cells into neuron-like cells [57]. However, they could not observe inward sodium currents. According to our immunocytochemical studies, our results indicate that more than $80 \%$ of hADSCs appear to differentiate into neuron-like cells under specific in vitro culture conditions with bFGF and forskolin, and express several proteins specific to the neuronal phenotype that exhibit neuronal morphology (Figure 3a, 3b). Furthermore, approximately $75 \%$ of hADSCs demonstrate neural differentiation properties under electrophysiological study, with about -605 pA of voltage-dependent sodium currents being recorded in NI-hADSCs. These results suggest that bFGF and forskolin may be more effective than BDNF, retinoic acid, IBMX, indomethacin, and insulin in inducing the neural differentiation of ADSCs.

Although ADSCs have been used for years in the investigation of cell replacement therapy and differentiation, information about ion channel expression remains undocumented. Undifferentiated bone marrow-derived hMSCs are known to express the TTX-sensitive sodium channel gene (NE-Na), potassium channel genes (MaxiK, $\mathrm{Kv1.4}, \mathrm{Kv} 4.2, \mathrm{Kv} 4.3$, and Eag1) and the calcium channel gene (CACNA1C) [56,57]. However, this study indicates that primary hADSCs also express ion channel mRNAs, including potassium channel genes (MaxiK, Kv1.4, Kv4.2, and Eag2), calcium channel genes (CACNA1C and CACN1G), and the TTX-insensitive sodium channel gene (SCN5A), but do not exhibit the TTX-sensitive sodium channel gene (NE-Na) and other voltage-dependent potassium channel genes (Kv4.3 and Eag1) (Figure $4 d)$. Since the primary hADSCs did not display voltagedependent sodium currents prior to neural differentiation, gene expression results are consistent with electrophysiological data. However, neural induction with bFGF and forskolin increased the expression of these ion channel genes, particularly those expressed in the primary hMSCs, and induced three novel functional ion channel genes (NE-Na, Kv4.3, and Eag1), indicating the differentiation of hADSCs towards neuronal cells. This result is an initial finding on the expression of ionic channel genes in both primary- and NI-hADSCs.

\section{Conclusions}

The present study demonstrates that hADSCs have the ability to act as mesenchymal stem cells and can effectively differentiate into functional neuron-like cells with bFGF and forskolin treatment.

\section{Methods}

\section{Preparation of hADSCs}

Fat tissue from the human earlobe was obtained from healthy donors 4-20 years of age. Informed consent was obtained from all donors according to the Guidelines of the Ethics Committee at Chonnam National University Medical School. Human mesenchymal stem cells were isolated from fat tissue samples according to the previous report [32]. Human fat tissue was rinsed with PBS containing $1 \%$ penicillin-streptomycin (Hyclone, Logan, UT, USA), cut into small pieces, and then incubated in a solution containing $0.075 \%$ collagenase type IA (Sigma Chemical Co., St. Louis, MO. USA) for $1 \mathrm{~h}$ at $37^{\circ} \mathrm{C}$ with vigorous shake. The top lipid layer was removed and the remaining liquid portion was centrifuged at $220 \mathrm{~g}$ for 15 min at room temperature. The pellet was treated with 160 $\mathrm{mM} \mathrm{NH}_{4} \mathrm{Cl}$ (Sigma Chemical Co.) for $10 \mathrm{~min}$ to remove red blood cells. The remaining cells were filtered through a 40- $\mu$ m nylon mesh filter (BD Falcon, Franklin Lakes, NJ, 
USA), and plated at a density of $1 \times 10^{5}$ cells in a $10-\mathrm{cm}$ dish. Isolated human mesenchymal stem cells were grown as adherent cultures in Dulbecco's modified Eagle's medium (DMEM; Hyclone, Logan, UT, USA) supplemented with $10 \%$ fetal bovine serum (FBS; Hyclone) and $1 \%$ penicillin-streptomycin. After four weeks, cells were grown to approximately $80 \%$ confluence in a $37^{\circ} \mathrm{C}$ humidified incubator with a $5 \% \mathrm{CO}_{2}$ and $95 \%$ air environment. The morphological features of the hADSCs were the same as those previously described $[12,33]$. The hADSCs used in the present study were from passages 3 to 7 .

\section{Fluorescence-activated cell sorting}

For fluorescence-activated cell sorter (FACS) analysis, hADSCs were harvested in trypsin containing ethylenediaminetetraacetic acid (Hyclone), washed twice with phosphate-buffered saline (PBS; Amresco, Inc., Solon, $\mathrm{OH}, \mathrm{USA}$ ), and stained on ice according to the manufacturer's recommendations with monoclonal antibodies (BD Biosciences PharMingen ${ }^{\mathrm{nw}}$, Heidelberg, Germany), including PE-CD13, FITC-CD14, FITC-CD34, PE-CD44, FITC-CD45, PE-CD90, and PE-CD166. At least 10,000 events were collected and analyzed with flow cytometry (BD FACSCalibur System, BD Biosciences Immunocytometry System, Heidelberg, Germany).

\section{Differentiation culture conditions}

Adipogenic differentiation of hADSCs was induced by growing the cells in adipocyte differentiation basal medium containing an adipogenic supplement (Gibco BRL, Grand Island, NY, USA) for one week. One week following induction, cells were stained with oil-red $\mathrm{O}$ (Sigma Chemical Co.). Human fat tissue was used as a positive control. For negative controls, oil-red $\mathrm{O}$ was omitted from the reaction series. To induce osteogenic differentiation, hADSCs were cultured in an osteogenic differentiation basal medium containing osteogenic supplement (Gibco BRL). After two weeks, osteogenic differentiation was evaluated with alkaline phosphatase staining (TRACP \& ALP double-stain kit, Takara Bio Inc. Shiga, Japan). Human bone tissue was used as a positive control. For negative controls, the substrate for alkaline phosphatase was omitted from the reaction series. For chondrogenic differentiation, cells were cultured for three weeks in the presence of chondrogenic supplement in chondrogenic differentiation basal medium (Gibco BRL). This medium was replaced every 3-4 days for three weeks. The development of chondrogenic differentiation was determined by staining the medium with Alcian blue (Sigma Chemical Co.). Human cartilage tissue was served as a positive control. For negative controls, oil-red $\mathrm{O}$ was omitted from the reaction series. To induce neural differentiation, hADSCs were grown in DMEM containing $1 \%$ FBS and supplementary $100 \mathrm{ng} / \mathrm{mL}$ basic fibroblast growth factor (bFGF, Invitrogen Co., Carlsbad, CA, USA) for seven days. The cells were then incubated in the presence of $10 \mu \mathrm{M}$ forskolin (Sigma Chemical Co.) and over the next seven days, the cells were subjected to immunocytochemical, electrophysiological, and RT-PCR analyses.

\section{Reverse transcriptase-polymerase chain reaction (RT-PCR) analysis}

To analyze the relative expression of different mRNAs, the amount of cDNA was normalized based on signals from the ubiquitously expressed GAPDH [69]. Total RNA was extracted from cultured cells by using TriReagent (Molecular Research Center, Inc., Cincinnati, OH, USA), and $1 \mu \mathrm{g}$ of cDNA was reverse-transcribed using a reverse transcriptase (M-MLV, Gibco BRL) for 90 min at $42^{\circ} \mathrm{C}$. PCR primer (Bioneer Co., Daejeon, Korea) pairs were selected to discriminate between cDNA and genomic DNA by using individual primers specific to different exons, when possible. The cDNA was amplified by 35 cycles of PCR (Takara Bio Inc.) using Ex-Taq polymerase (Takara Bio Inc.). Forward and reverse PCR oligonucleotide primers selected to amplify the cDNA are listed in Table 2. RT-PCR products were separated electrophoretically on $2 \%$ agarose gels (Sigma Chemical Co.).

\section{Immunocytochemistry}

The immunocytochemical determination of cell type specific markers in hADSCs was performed as follows: Cells were grown on poly-L-lysine-coated aclar plastic coverslips for 10 days, fixed for 15 min with $4 \%$ paraformaldehyde (PFA; Sigma Chemical Co.), and blocked for $20 \mathrm{~min}$ with $0.5 \%$ Triton X-100 (Sigma Chemical Co.), which included 10\% normal goat serum (Vector Laboratories, Inc., Burlingame, CA, USA) in PBS. Anti-nestin (1:300), anti-neuron-specific class III $\beta$-tubulin (Tuj1, 1:300), anti-microtubule associated protein-2 (MAP2, 1:200), anti-neurofilament-L (NFL, 1:300), anti-neurofilament-M (NFM, 1:300), anti-neurofilament-H (NFH, 1:300), antineuron specific enolase (NSE, 1:100), anti-neuronal specific nuclear protein (NeuN, 1:300), anti-growth associated protein 43 (GAP43, 1:300), anti-synaptosomeassociated protein $25 \mathrm{kDa}$ (SNAP25, 1:200), anti-glial fibrillary acidic protein (GFAP, 1:300), or anti-2',3'-cyclic nucleotide 3'-phosphodiesterase (CNPase, 1:100) were then added. Primary antibodies were incubated overnight at $4^{\circ} \mathrm{C}$. After washing, Alexa 546-conjugated goat antimouse antibody (Molecular Probes, Invitrogen Co., CA, USA) was used as a secondary antibody and incubated at room temperature for $1 \mathrm{~h}$. Nuclei were stained with DAPI for cell counting. Cells were observed using a Zeiss LSM510 confocal microscope (Carl Zeiss, Jena, Germany). All primary antibodies were purchased from Chemicon (Chemicon, Temecula, CA, USA). Experi- 
ments were performed in triplicate and the percentage of positive cells was randomly calculated. To perform quantitative analysis, the numbers of positive cells was counted on each acquired image by ImageJ1.42 (NIH), and the ratio to the number of nuclei was analyzed for each antigen. For negative controls, primary antibody was omitted from the reaction series. HB1.F3 human neural stem cells and postmortem human brain tissue were served as positive controls for nestin and the other antigens, respectively.

To stain the adipose cells with oil-red $\mathrm{O}$, cells were fixed with 4\% PFA for $15 \mathrm{~min}$, washed with 60\% isopropanol (Sigma Chemical Co.) and air-dried. A fresh $60 \%$ oilred $\mathrm{O}$ working solution was prepared from stock solution $(0.7 \mathrm{~g}$ oil-red $\mathrm{O}$ in $200 \mathrm{~mL}$ isopropanol) and filtered through a $45 \mu \mathrm{M}$ syringe filter. Cells were stained with the working solution for $45 \mathrm{~min}$ and then washed five times with distilled water. During the alkaline phosphatase staining for osteoblasts, cells were fixed with 4\% PFA for $15 \mathrm{~min}$, washed with PBS, and incubated with alkaline phosphatase (using Takara kit) for $20 \mathrm{~min}$. During Alcin blue staining for chondrocytes, cells were fixed 4\% PFA for $15 \mathrm{~min}$ and then incubate with 3\% acetic acid. Cells were stained with $1 \%$ Alcian blue in $3 \%$ acetic acid $(\mathrm{pH}$ 2.5) for $30 \mathrm{~min}$ and then washed with distilled water. The cells were examined using a light microscope (Olympus DP70, Japan).

\section{Electrophysiology}

Cells grown on coverslips for two weeks were placed in a recording chamber on the stage of an inverted microscope (Eclipse TE 2000-S, Nikon; Tokyo, Japan), and voltage-dependent ionic currents and resting membrane potentials were recorded using the whole-cell patch clamp technique [70]. Patch micropipettes having a resistance of 2-4 $\mathrm{M} \Omega$ were pulled with an electrode puller (PP830, Narishige, Japan) from borosilicate glass capillaries (G150T-3, Warner Instruments, CT, USA) and firepolished using a microforge (MF-790, Narishige). Pipettes were filled with an intracellular-like solution containing $140 \mathrm{mM} \mathrm{KCl}, 5 \mathrm{mM} \mathrm{NaCl}, 1 \mathrm{mM} \mathrm{CaCl}, 10$ mM HEPES, 5 mM EGTA, $2 \mathrm{mM} \mathrm{Mg-ATP} \mathrm{for} \mathrm{the} \mathrm{inward}$ $\mathrm{Na}^{+}$currents and outward $\mathrm{K}^{+}$currents to record. The $\mathrm{pH}$ was adjusted to 7.3 with $\mathrm{KOH}$ and filtered before use. The standard external solution was comprised of $140 \mathrm{mM}$

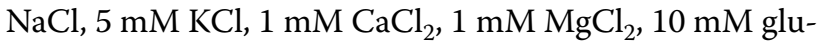
cose, $10 \mathrm{mM}$ HEPES. The solutions were adjusted to $\mathrm{pH}$ 7.3 with $\mathrm{NaOH}$. Whole-cell currents were recorded at 22$24^{\circ} \mathrm{C}$ using a patch-clamp amplifier (Axopatch 200B, Axon Instruments, Foster City, CA, USA) and digitized by an analog-to-digital interface (Digidata 1320, Axon Instruments). Membrane currents were low-pass filtered at $2 \mathrm{kHz}$, sampled at $50 \mathrm{kHz}$, and then stored on the hard disk of an IBM-compatible computer using pClamp8.2
(Axon Instruments). The cells were held at $-70 \mathrm{mV}$ and depolarized in $10 \mathrm{mV}$ intervals between -60 and $+40 \mathrm{mV}$. The bathing or drug-containing solutions were applied to the recording chamber with a gravity-fed perfusion system.

\section{Statistics}

Protein and mRNA levels were quantified by measuring the optical density of each band using computer-assisted densitometry (NIH Image analysis program, version 1.61). All values are expressed as the mean \pm SEM. The one-way ANOVA test (Bonferroni post hoc comparison) was used to analyze differences between groups, with $P<$ 0.05 being considered significant.

\section{Authors' contributions \\ SJ: Perform the main experimental work, collection and assembly of data, data analysis and interpretation, manuscript writing \\ $\mathrm{H}-\mathrm{HC}$ : Proving of human tissue \\ Y-BC: Financial support \\ J-SP: Discussion and comment of the data and manuscript \\ $\mathrm{H}-\mathrm{SJ}$ : Conception and design, data analysis and interpretation, manuscript writ- ing, final approval of manuscript \\ All authors read and approved the final manuscript}

\section{Acknowledgements}

This work was supported by the Korea Research Foundation Grant funded by the Korean Government (Basic Promotion Fund: KRF-2008-E00148) and a grant (CRI08067-1) of Chonnam National University Hospital Research Institute of Clinical Medicine.

Author Details

1Department of Physiology, Chonnam National University Medical School, Gwangju 501190, Republic of Korea, 2Department of Otolaryngology, Chonnam National University Medical School, Gwangju 501190, Republic of Korea, ${ }^{3}$ Brain Korea 21 Project, Center for Biomedical Human Resources at Chonnam National University, Gwangju, 501-190, Republic of Korea and 4Research Institute of Medical Sciences, Chonnam National University, Gwangju 501-190, Republic of Korea

Received: 29 October 2009 Accepted: 16 April 2010 Published: 16 April 2010

\section{References}

1. Burdon T, Smith A, Savatier P: Signalling, cell cycle and pluripotency in embryonic stem cells. Trends Cell Biol 2002, 12(9):432-438.

2. Jiang Y, Henderson D, Blackstad M, Chen A, Miller RF, Verfaillie CM: Neuroectodermal differentiation from mouse multipotent adult progenitor cells. Proc Natl Acad Sci USA 2003, 100(Suppl 1):11854-11860.

3. Phinney DG, Prockop DJ: Concise review: mesenchymal stem/ multipotent stromal cells: the state of transdifferentiation and modes of tissue repair--current views. Stem Cells 2007, 25(11):2896-2902.

4. Yu J, Thomson JA: Pluripotent stem cell lines. Genes Dev 2008, 22(15):1987-1997

5. Lenoir N: Europe confronts the embryonic stem cell research challenge. Science 2000, 287(5457):1425-1427.

6. Young FE: A time for restraint. Science 2000, 287(5457):1424

7. Bang OY, Lee JS, Lee PH, Lee G: Autologous mesenchymal stem cell transplantation in stroke patients. Ann Neurol 2005, 57(6):874-882.

8. De Keyser J: Autologous mesenchymal stem cell transplantation in stroke patients. Ann Neurol 2005, 58(4):653-654. author reply 654-655

9. Dezawa M, Kanno H, Hoshino M, Cho H, Matsumoto N, Itokazu Y, Tajima N, Yamada H, Sawada H, Ishikawa H, Mimura T, Kitada M, Suzuki Y, Ide C: Specific induction of neuronal cells from bone marrow stromal cells and application for autologous transplantation. J Clin Invest 2004, 113(12):1701-1710. 
10. Jung DI, Ha J, Kang BT, Kim JW, Quan FS, Lee JH, Woo EJ, Park HM: A comparison of autologous and allogenic bone marrow-derived mesenchymal stem cell transplantation in canine spinal cord injury. Neurol Sci 2009, 285(1-2):67-77.

11. Kang SK, Shin MJ, Jung JS, Kim YG, Kim CH: Autologous adipose tissuederived stromal cells for treatment of spinal cord injury. Stem Cells Dev 2006, 15(4):583-594.

12. Anghileri E, Marconi S, Pignatelli A, Cifelli P, Galie M, Sbarbati A, Krampera $\mathrm{M}$, Belluzzi $\mathrm{O}$, Bonetti B: Neuronal differentiation potential of human adipose-derived mesenchymal stem cells. Stem Cells Dev 2008, 17(5):909-916

13. Jiang $Y$, Jahagirdar BN, Reinhardt RL, Schwartz RE, Keene CD, OrtizGonzalez XR, Reyes M, Lenvik T, Lund T, Blackstad M, Du J, Aldrich S, Lisberg A, Low WC, Largaespada DA, Verfaillie CM: Pluripotency of mesenchymal stem cells derived from adult marrow. Nature 2002, 418(6893):41-49.

14. Peng L, Jia Z, Yin X, Zhang X, Liu Y, Chen P, Ma K, Zhou C: Comparative analysis of mesenchymal stem cells from bone marrow, cartilage, and adipose tissue. Stem Cells Dev 2008, 17(4):761-773.

15. Fan J, Varshney RR, Ren L, Cai D, Wang DA: Synovium-derived mesenchymal stem cells: a new cell source for musculoskeletal regeneration. Tissue Eng Part B Rev 2009, 15(1):75-86.

16. Yoshimura H, Muneta T, Nimura A, Yokoyama A, Koga H, Sekiya I: Comparison of rat mesenchymal stem cells derived from bone marrow, synovium, periosteum, adipose tissue, and muscle. Cell Tissue Res 2007, 327(3):449-462.

17. Zhang S, Muneta T, Morito T, Mochizuki T, Sekiya I: Autologous synovial fluid enhances migration of mesenchymal stem cells from synovium of osteoarthritis patients in tissue culture system. J Orthop Res 2008, 26(10):1413-1418

18. Janjanin S, Djouad F, Shanti RM, Baksh D, Gollapudi K, Prgomet D, Rackwitz L, Joshi AS, Tuan RS: Human palatine tonsil: a new potential tissue source of multipotent mesenchymal progenitor cells. Arthritis Res Ther 2008, 10(4):R83.

19. Jung M, Kaszap B, Redohl A, Steck E, Breusch S, Richter W, Gotterbarm T: Enhanced early tissue regeneration after matrix assisted autologous mesenchymal stem cell transplantation in full thickness chondral defects in a minipig model. Cell Transplant 2009, 18(8):923-932.

20. Krampera M, Marconi S, Pasini A, Galie M, Rigotti G, Mosna F, Tinelli M, Lovato L, Anghileri E, Andreini A, Pizzolo G, Sbarbati A, Bonetti B: Induction of neural-like differentiation in human mesenchymal stem cells derived from bone marrow, fat, spleen and thymus. Bone 2007 40(2):382-390

21. Padovan CS, Jahn K, Birnbaum T, Reich P, Sostak P, Strupp M, Straube A: Expression of neuronal markers in differentiated marrow stromal cells and CD133+ stem-like cells. Cell Transplant 2003, 12(8):839-848.

22. Freed CR, Greene PE, Breeze RE, Tsai WY, DuMouchel W, Kao R, Dillon S, Winfield H, Culver S, Trojanowski JQ, Eidelberg D, Fahn S: Transplantation of embryonic dopamine neurons for severe Parkinson's disease. NEngl J Med 2001, 344(10):710-719.

23. Rakic P: Adult neurogenesis in mammals: an identity crisis. J Neurosci 2002, 22(3):614-618

24. Hofstetter CP, Schwarz EJ, Hess D, Widenfalk J, El Manira A, Prockop DJ Olson L: Marrow stromal cells form guiding strands in the injured spinal cord and promote recovery. Proc Natl Acad Sci USA 2002, 99(4):2199-2204.

25. Kim SS, Yoo SW, Park TS, Ahn SC, Jeong HS, Kim JW, Chang DY, Cho KG, Kim SU, Huh Y, Lee JE, Lee SY, Lee YD, Suh-Kim H: Neural induction with neurogenin 1 increases the therapeutic effects of mesenchymal stem cells in the ischemic brain. Stem Cells 2008, 26(9):2217-2228.

26. Nagai A, Kim WK, Lee HJ, Jeong HS, Kim KS, Hong SH, Park IH, Kim SU: Multilineage potential of stable human mesenchymal stem cell line derived from fetal marrow. PLoS One 2007, 2(12):e1272.

27. Woodbury D, Schwarz EJ, Prockop DJ, Black IB: Adult rat and human bone marrow stromal cells differentiate into neurons. Journal of Neuroscience Research 2000, 61(4):364-370.

28. Hung SC, Cheng H, Pan CY, Tsai MJ, Kao LS, Ma HL: In vitro differentiation of size-sieved stem cells into electrically active neural cells. Stem Cells 2002, 20(6):522-529.

29. Egusa H, Schweizer FE, Wang CC, Matsuka Y, Nishimura I: Neuronal differentiation of bone marrow-derived stromal stem cells involves suppression of discordant phenotypes through gene silencing. J Biol Chem 2005, 280(25):23691-23697.

30. Caspar-Bauguil S, Cousin B, Galinier A, Segafredo C, Nibbelink M, Andre M, Casteilla L, Penicaud L: Adipose tissues as an ancestral immune organ: site-specific change in obesity. FEBS Lett 2005, 579(17):3487-3492.

31. Casteilla L, Dani C: Adipose tissue-derived cells: from physiology to regenerative medicine. Diabetes Metab 2006, 32(5 Pt 1):393-401.

32. Lin G, Garcia M, Ning H, Banie L, Guo YL, Lue TF, Lin CS: Defining stem and progenitor cells within adipose tissue. Stem Cells Dev 2008, 17(6):1053-1063.

33. Park JR, Jung JW, Lee YS, Kang KS: The roles of Wnt antagonists Dkk1 and sFRP4 during adipogenesis of human adipose tissue-derived mesenchymal stem cells. Cell Prolif 2008, 41(6):859-874.

34. Zuk PA, Zhu M, Ashjian P, De Ugarte DA, Huang Jl, Mizuno H, Alfonso ZC Fraser JK, Benhaim $\mathrm{P}$, Hedrick MH: Human adipose tissue is a source of multipotent stem cells. Mol Biol Cell 2002, 13(12):4279-4295.

35. Tholpady SS, Katz AJ, Ogle RC: Mesenchymal stem cells from rat visceral fat exhibit multipotential differentiation in vitro. Anat Rec A Discov Mol Cell Evol Biol 2003, 272(1):398-402.

36. Kingham PJ, Kalbermatten DF, Mahay D, Armstrong SJ, Wiberg M, Terenghi G: Adipose-derived stem cells differentiate into a Schwann cell phenotype and promote neurite outgrowth in vitro. Exp Neurol 2007, 207(2):267-274.

37. Ning H, Lin G, Fandel T, Banie L, Lue TF, Lin CS: Insulin growth factor signaling mediates neuron-like differentiation of adipose-tissuederived stem cells. Differentiation 2008, 76(5):488-494.

38. Safford KM, Hicok KC, Safford SD, Halvorsen YD, Wilkison WO, Gimble JM Rice HE: Neurogenic differentiation of murine and human adiposederived stromal cells. Biochem Biophys Res Commun 2002, 294(2):371-379.

39. Safford KM, Safford SD, Gimble JM, Shetty AK, Rice HE: Characterization of neuronal/glial differentiation of murine adipose-derived adult stromal cells. Exp Neurol 2004, 187(2):319-328.

40. Xu Y, Liu Z, Liu L, Zhao C, Xiong F, Zhou C, Li Y, Shan Y, Peng F, Zhang C: Neurospheres from rat adipose-derived stem cells could be induced into functional Schwann cell-like cells in vitro. BMC Neurosci 2008, 9:21.

41. Chen Y, Teng FY, Tang BL: Coaxing bone marrow stromal mesenchymal stem cells towards neuronal differentiation: progress and uncertainties. Cell Mol Life Sci 2006, 63(14):1649-1657.

42. Montzka K, Lassonczyk N, Tschoke B, Neuss S, Fuhrmann T, Franzen R, Smeets R, Brook GA, Woltje M: Neural differentiation potential of human bone marrow-derived mesenchymal stromal cells: misleading marker gene expression. BMC Neurosci 2009, 10:16.

43. Lu P, Blesch A, Tuszynski MH: Induction of bone marrow stromal cells to neurons: differentiation, transdifferentiation, or artifact? Journal of Neuroscience Research 2004, 77(2):174-191.

44. Neuhuber B, Gallo G, Howard L, Kostura L, Mackay A, Fischer I: Reevaluation of in vitro differentiation protocols for bone marrow stromal cells: disruption of actin cytoskeleton induces rapid morphological changes and mimics neuronal phenotype. Journal of Neuroscience Research 2004, 77(2):192-204.

45. Terada N, Hamazaki T, Oka M, Hoki M, Mastalerz DM, Nakano Y, Meyer EM, Morel L, Petersen BE, Scott EW: Bone marrow cells adopt the phenotype of other cells by spontaneous cell fusion. Nature 2002, 416(6880):542-545.

46. Wislet-Gendebien S, Hans G, Leprince P, Rigo JM, Moonen G, Rogister B: Plasticity of cultured mesenchymal stem cells: switch from nestinpositive to excitable neuron-like phenotype. Stem Cells 2005, 23(3):392-402

47. Croft AP, Przyborski SA: Formation of neurons by non-neural adult stem cells: potential mechanism implicates an artifact of growth in culture. Stem Cells 2006, 24(8):1841-1851.

48. Ning H, Lin G, Lue TF, Lin CS: Neuron-like differentiation of adipose tissue-derived stromal cells and vascular smooth muscle cells. Differentiation 2006, 74(9-10):510-518.

49. Bunnell BA, Flaat M, Gagliardi C, Patel B, Ripoll C: Adipose-derived stem cells: isolation, expansion and differentiation. Methods 2008, 45(2):115-120

50. Strem BM, Hicok KC, Zhu M, Wulur I, Alfonso Z, Schreiber RE, Fraser JK, Hedrick MH: Multipotential differentiation of adipose tissue-derived stem cells. Keio J Med 2005, 54(3):132-141. 
51. Schaffler A, Buchler C: Concise review: adipose tissue-derived stromal cells--basic and clinical implications for novel cell-based therapies. Stem Cells 2007, 25(4):818-827.

52. Wagner W, Wein F, Seckinger A, Frankhauser M, Wirkner U, Krause U, Blake J, Schwager C, Eckstein V, Ansorge W, Ho AD: Comparative characteristics of mesenchymal stem cells from human bone marrow adipose tissue, and umbilical cord blood. Exp Hematol 2005, 33(11):1402-1416.

53. de Villiers JA, Houreld N, Abrahamse H: Adipose derived stem cells and smooth muscle cells: implications for regenerative medicine. Stem Cell Rev 2009, 5(3):256-265.

54. Guilak F, Lott KE, Awad HA, Cao Q, Hicok KC, Fermor B, Gimble JM: Clonal analysis of the differentiation potential of human adipose-derived adult stem cells. J Cell Physiol 2006, 206(1):229-237.

55. Kang SK, Lee DH, Bae YC, Kim HK, Baik SY, Jung JS: Improvement of neurological deficits by intracerebral transplantation of human adipose tissue-derived stromal cells after cerebral ischemia in rats. Exp Neurol 2003, 183(2):355-366

56. Lee TH, Yoon JG: Intracerebral transplantation of human adipose tissue stromal cells after middle cerebral artery occlusion in rats. J Clin Neurosci 2008, 15(8):907-912.

57. Ashjian PH, Elbarbary AS, Edmonds B, DeUgarte D, Zhu M, Zuk PA, Lorenz HP, Benhaim P, Hedrick MH: In vitro differentiation of human processed lipoaspirate cells into early neural progenitors. Plast Reconstr Surg 2003, 111(6):1922-1931.

58. Fujimura J, Ogawa R, Mizuno H, Fukunaga Y, Suzuki H: Neural differentiation of adipose-derived stem cells isolated from GFP transgenic mice. Biochem Biophys Res Commun 2005, 333(1):1 16-121.

59. Case J, Horvath TL, Howell JC, Yoder MC, March KL, Srour EF: Clonal multilineage differentiation of murine common pluripotent stem cells isolated from skeletal muscle and adipose stromal cells. Ann N Y Acad Sci 2005, 1044:183-200.

60. Whittemore SR, Morassutti DJ, Walters WM, Liu RH, Magnuson DS: Mitogen and substrate differentially affect the lineage restriction of adult rat subventricular zone neural precursor cell populations. Exp Cell Res 1999, 252(1):75-95.

61. Kim SS, Choi JM, Kim JW, Ham DS, Ghil SH, Kim MK, Kim-Kwon Y, Hong SY, Ahn SC, Kim SU, Lee YD, Suh-Kim H: cAMP induces neuronal differentiation of mesenchymal stem cells via activation of extracellular signal-regulated kinase/MAPK. Neuroreport 2005, 16(12):1357-1361.

62. Rooney GE, Howard L, O'Brien T, Windebank AJ, Barry FP: Elevation of CAMP in mesenchymal stem cells transiently upregulates neural markers rather than inducing neural differentiation. Stem Cells Dev 2009, 18(3):387-398.

63. Cho KJ, Trzaska KA, Greco SJ, McArdle J, Wang FS, Ye JH, Rameshwar P: Neurons derived from human mesenchymal stem cells show synaptic transmission and can be induced to produce the neurotransmitter substance $P$ by interleukin-1 alpha. Stem Cells 2005, 23(3):383-391.

64. Biella G, Di Febo F, Goffredo D, Moiana A, Taglietti V, Conti L, Cattaneo E, Toselli M: Differentiating embryonic stem-derived neural stem cells show a maturation-dependent pattern of voltage-gated sodium current expression and graded action potentials. Neuroscience 2007 , 149(1):38-52

65. Yang LY, Liu XM, Sun B, Hui GZ, Fei J, Guo LH: Adipose tissue-derived stromal cells express neuronal phenotypes. Chin Med J (Engl) 2004, 117(3):425-429.

66. Kim BJ, Seo JH, Bubien JK, Oh YS: Differentiation of adult bone marrow stem cells into neuroprogenitor cells in vitro. Neuroreport 2002, 13(9):1185-1188.

67. D'Ilppolito G, Diabira S, Howard GA, Menei P, Roos BA, Schiller PC: Marrowisolated adult multilineage inducible (MIAMI) cells, a unique population of postnatal young and old human cells with extensive expansion and differentiation potential. J Cell Sci 2004, 117:2971-2981.

68. Tondreau T, Lagneaux L, Dejeneffe M, Massy M, Mortier C, Delforge A, Bron $D$ : Bone marrow-derived mesenchymal stem cells already express specific neural proteins before any differentiation. Differentiation 2004, 72(7):319-326

69. Jang S, Jeong HS, Park JS, Kim YS, Jin CY, Seol MB, Kim BC, Lee MC Neuroprotective effects of (-)-epigallocatechin-3-gallate against quinolinic acid-induced excitotoxicity via PI3K pathway and NO inhibition. Brain Res 2010, 1313:25-33.
70. Jeong HS, Kim YS, Park JS: Modulation of neuronal activity by EGCG. Brain Res 2005, 1047(2):267-270

doi: $10.1186 / 1471-2121-11-25$

Cite this article as: Jang et al., Functional neural differentiation of human adipose tissue-derived stem cells using bFGF and forskolin BMC Cell Biology 2010, 11:25

\section{Submit your next manuscript to BioMed Central} and take full advantage of:

- Convenient online submission

- Thorough peer review

- No space constraints or color figure charges

- Immediate publication on acceptance

- Inclusion in PubMed, CAS, Scopus and Google Scholar

- Research which is freely available for redistribution

Submit your manuscript at www.biomedcentral.com/submit
C Biomed Central 